\title{
Alfred Wegener e a revolução Copernicana da geologia
}

\author{
Ernesto Luiz, Lavina ${ }^{1}$
}

\begin{abstract}
Resumo A passagem do século XIX para o século XX foi marcada por sucessivas revoluções científicas que ocasionaram uma profunda modificação no conceito de realidade. Átomos, radiação eletromagnética e deslocamentos na objetividade dos conceitos newtonianos fizeram com que a realidade do ver para crer (realismo materialista) fosse rapidamente substituída por outra, permeada de conceitos fundamentados em teorias que se localizavam para além do senso comum. Apesar das imensas transformações introduzidas, a assimilação do novo arcabouço teórico foi relativamente rápida. Houve, entretanto, uma notável exceção. Uma construção teórica inovadora deste período foi absolutamente rejeitada pela comunidade científica. Quando, em 1912, Wegener propôs a existência, no passado distante, de um supercontinente que veio posteriormente a fragmentar-se dando origem aos atuais continentes, instalou-se um verdadeiro estado de guerra no âmbito das ciências da Terra. Houve, de fato, uma repulsa que necessitava ser manifesta em todas as oportunidades. Porquê as idéias de Wegener não foram aceitas? Talvez por que a geografia antiga da Terra não era considerada problema. Talvez porque suas evidências nada mais eram do que os resultados das pesquisas dos mais eminentes cientistas, apenas que reorganizados e reinterpretados em suas implicações. Wegener criou um imenso problema onde não havia problemas, e propôs uma solução que se encontrava fora do arcabouço teórico da ciência. A formulação de sua teoria implicava a negação de muitos paradigmas, pois não havia como deduzir ou antever a movimentação continental nas teorias anteriores. Wegener foi um pensador original, mas não foi um fato único, pelo contrário, foi apenas um entre muitos cientistas notáveis do início do século XX. Cientistas que tinham em comum uma nova forma de organizar as evidências científicas. Talvez inspirados pelo neokantismo da Escola de Marburg, com sua idealização de que é o método que constrói os objetos do discurso científico.
\end{abstract}

Palavras-chave: história das geociências, deriva dos continentes, Neokantismo, Cohen, Cassirer

\begin{abstract}
Alfred Wegener and the Copernican revolution of geology. The transition from the $19^{\text {th }}$ to the $20^{\text {th }}$ century was marked by successive scientific revolutions, which resulted in great changes to the concept of reality. Atoms, electromagnetic radiation and displacements in the objectiveness of the Newtonian concepts quickly replaced the "see to believe" concept (materialistic realism) with a different notion permeated with concepts based on theories that were in a realm beyond common sense. In spite of the immense transformations thus introduced, the new theoretical framework was assimilated relatively fast. There was, however, one noteworthy exception: an innovative theory from this period that was fiercely spurned by the scientific community. When, in 1912, Wegener proposed the existence, in the distant past, of a supercontinent that would have later fragmented, originating the current continents, a state of war was practically declared in the field of Earth sciences. The idea inspired in fact a loathing that needed be expressed at every opportunity. Why then were his ideas not accepted? Maybe the reason was that the ancient geography of the Earth was not considered a problem. Maybe because the evidences proposed by Wegener were nothing more than that the results of the researches conducted by the most eminent scientists, simply reorganized and reinterpreted in their implications. Wegener created a massive problem where no problems were detected, and proposed a solution that was outside the theoretical framework of Science. The formulation of his hypothesis was only possible by denying many paradigms, since there was no way to deduce or to predict the continental drift in previous theories. Wegener was an original thinker, but he was not the only one. On the contrary, he was just one among many notable scientists at the beginning of the $20^{\text {th }}$ century, whose common ground was a new way to organize scientific evidence. Perhaps inspired by the neoKantianism of the Marburg's School, with its concept that the method builds the objects of scientific discourse.
\end{abstract}

Keywords: geoscience history, continental drift, Neo-Kantianism, Cohen, Cassirer

INTRODUÇÃO Filho de pastor evangélico, Alfred Lothar Wegener nasceu em Berlim em 1880. Doutorouse em Astronomia e foi professor da Universidade de Marburg, onde lecionava Meteorologia, ciência da sua predileção, e publicou trabalho considerado clássico sobre a termodinâmica da atmosfera. Era apaixonado pela exploração da Groenlândia, onde esteve por três vezes e morreu congelado durante expedição em 1930, quando tentava medir a espessura da capa de gelo por intermédio de uma metodologia revolucionária, que se utilizava da reflexão e tempo de retorno de ondas sísmicas (McCoy 2006). Praticava alpinismo, esqui, e foi 
balonista experiente, tendo batido o recorde mundial de permanência no ar em vôo de balão. Na primeira guerra mundial serviu como oficial-júnior. Após a guerra, foi diretor do Departamento de Pesquisa Meteorológica do Observatório Marinho de Hamburgo. Posteriormente, lecionou Meteorologia e Geofísica na Universidade de Graz (Áustria) (Hallam 1983; Wyllie 1979, McCoy 2006).

Wegener propôs, em 1912, uma concepção de evolução geográfica que ocasionou a maior controvérsia da história da Geologia. Para ele, teria existido, no passado, um imenso continente (Pangea), que posteriormente viria a fragmentar-se, dando origem aos continentes atuais (Fig. 1). A hipótese, mais conhecida sob a designação geral de "Teoria da Deriva dos Continentes", fez suscitar, na comunidade científica geológica, um terrível mal-estar. A ideia de imensos continentes vagando como jangadas, à deriva, sob influência de forças desconhecidas, causava desconforto a leigos e cientistas; abalava a convicção do senso comum na "terra firme". Parecia mais a idealização de um louco, e Wegener foi assim chamado. Mas, ao mesmo tempo, um volume imenso de observações e dados sugeria, de modo evidente, a correção de suas ideias. Estabelecia-se na cabeça de cada geólogo, geofísico ou paleontólogo, um conflito existencial, pois apesar das evidências, uma voz interior dizia que os continentes eram grandes e pesados demais para se moverem. No final, a razão foi dada a Wegener,
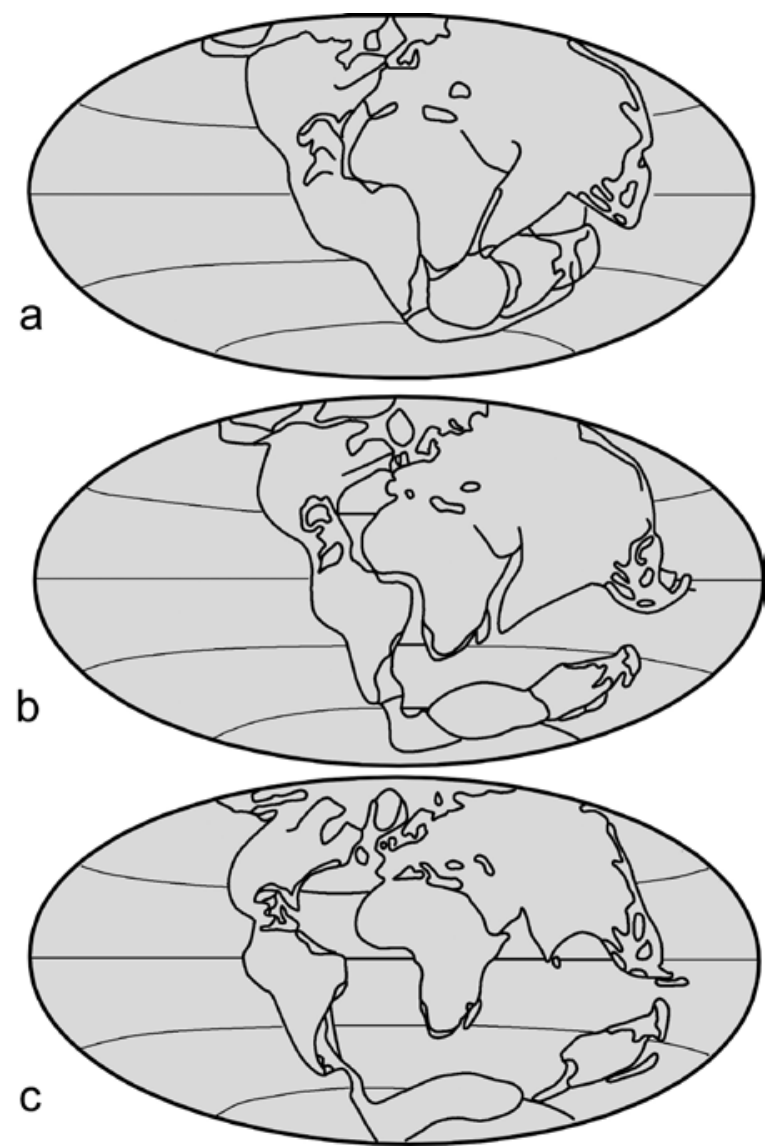

Figura 1 - O continente de Pangea (a). A fragmentação progressiva deu origem aos continentes atuais (b. Eoceno, c. Eoquaternário) (Wegener 1927). mas demorou bastante, cerca de cinquenta anos, para a ciência construir um mecanismo capaz de justificar a movimentação dos continentes.

É possível perceber que mesmo após a aceitação da Tectônica de Placas, continuou existindo um desconforto da comunidade científica com relação às ideias de Wegener. Pode-se afirmar, sem que isso constitua qualquer exagero, que a Deriva dos Continentes foi imposta a contragosto de toda uma comunidade de geólogos e geofísicos muito proeminentes. Por outro lado, para a nova geração que formulou a Tectônica de Placas, não era conveniente a conclusão de que haviam encontrado o mecanismo que faltava para a Deriva dos Continentes se tornar um paradigma completo. Era necessário exibir, antes, os méritos próprios da nova teoria, sem vinculá-la, mais que o estritamente necessário, à anterior. Talvez por isso, a importância do trabalho de Wegener tenda a aparecer, quase sempre, diminuída (e.g. Dietz \& Holden 1970, Tarling \& Runcorn 1973). Apanhados históricos sobre as origens da Tectônica de Placas dão sempre os créditos da "Deriva" a Wegener, no entanto, ora mostram com detalhe as falhas óbvias nos mecanismos por ele propostos para mover os continentes; ora omitem ou relatam de modo muito resumido as predições corretas feitas por Wegener. Em alguns casos, chega-se a pensar em curiosa coincidência entre os resultados alcançados por Wegener e os obtidos por meio da Tectônica de Placas (e.g. Heirtzler 1973).

Conforme procuraremos discutir, os méritos de Alfred Wegener são muito maiores que o usualmente aceito. Em comparação com a Física, podemos afirmar ter sido Wegener o Copérnico da Geologia. Tal como Copérnico, também Wegener não conseguiu convencer seus contemporâneos. Ao contrário de Copérnico, Wegener não teve o seu Galileu, ou melhor, teve um proto-Galileu - Alexander L. du Toit - que trilhou caminho errado. Por outro lado, os que compreenderam toda a importância histórica de Wegener deixaram-no cercado de certo aspecto místico. Ele aparece, muitas vezes, como alguém que tinha ideias avançadas demais para a época, e este seria o motivo principal das incompreensões. Isto pode em parte ser até verdadeiro, mas, quando se olha para a Física ou para a Geologia do início do século, percebe-se que ambas passavam por transformações tão profundas quanto às implícitas na migração continental. O tempo de Wegener é, precisamente, o tempo da desconstrução da mecânica newtoniana, ou seja, o tempo da Teoria da Relatividade, da elaboração do modelo atômico, da Mecânica Quântica, e também é o período da expansão da idade da Terra de alguns milhares para bilhões de anos (Lavina 2004).

A comunidade científica do início do século não era refratária às novas idéias, argumento que também aparece em alguns apanhados sobre Wegener. Ao contrário, gerava novas teorias com muita frequência; em muitos casos ideias tão afastadas do senso comum quanto a da movimentação continental. Aqui detectamos curiosa coincidência: quase todas as revoluções científicas do período provieram de cientistas educados possivelmente segundo uma nova derivação filosófica 
- o Neokantismo, em especial aquele desenvolvido na Universidade de Marburg, onde Wegener era professor.

Os aspectos históricos da Deriva dos Continentes foram já abordados em muitos trabalhos geológicos. Alguns deles, como os de Hallam (1975, 1983), Wyllie (1979), Allègre (1983) e McCoy (2006) apresentam pesquisa histórica bastante detalhada, constituindo-se em fontes inestimáveis de dados sobre a vida e a obra de Wegener. Mais importante ainda, são fontes nas quais se encontram reunidas as críticas contra ele dirigidas. Mas as análises desenvolvidas parecem sempre muito superficiais. Todos, invariavelmente, prendem-se às incompreensões e preconceitos, deixando em aberto as questões principais. Como se constituiu o pensador Alfred Wegener? Em qual contexto pode ele ser situado? Como foi possível a proposição da Deriva dos Continentes?

$\mathrm{Da}$ insatisfação com as respostas encontradas na bibliografia surgiu a ideia de discutir a Deriva dos Continentes, trazendo alguns elementos adicionais e tentando contextualizá-la à época. Conforme já referimos, Wegener não foi caso isolado no panorama científico do início do século, nem mesmo quanto ao método empregado. Incorporou-se, como inovador, a Plank, Rutherford, Bohr, Einstein, Born, Heisenberg, Schrödinger e a muitos outros cientistas notáveis.

Haverá, em algum ponto, um conflito, pois será concluído que não existiam elementos falseadores da Teoria da Deriva Continental, e que, portanto, ela deveria ter sido aceita. Por outro lado, tentaremos demonstrar que a "Deriva" não poderia ser aceita pela comunidade científica, pois afastava-se muito do considerado pela maioria como realidade. Este afastamento gerava outro tipo de conflito, uma vez que a Ciência, e em consequência as instituições científicas, necessitavam preservar sua imagem e credibilidade.

Torna-se importante referir que não pretendemos, em nenhum momento, apresentar Alfred Wegener como o ponto de origem - o fundador da Geologia contemporânea - aquele que viu antes e sofreu perseguições por parte dos que não conseguiam conceber a pertinência de suas ideias. Ressalta, de modo absolutamente claro, que Wegener não faz parte da Geologia formal da primeira metade do século XX. Ele esteve fisicamente lá, sempre presente como uma sombra incômoda, mas não se encontrava disponível (e este é o ponto central) no sentido de que suas ideias não podiam ser utilizadas pela comunidade científica. Somos nós que, atuando em época de domínio absoluto da Tectônica de Placas, olhamos em retrospectiva para a primeira metade do século passado e somos, a cada momento, surpreendidos com a clareza e precisão de suas idealizações.

\section{SÉCULO XX - AS REVOLUÇÕES CIENTÍFICAS}

SUCESSIVAS Os séculos XIX e XX se caracterizaram por muitas revoluções, abrangendo, no conjunto, praticamente todos os campos do conhecimento científico. Em especial, as décadas finais do século XIX e iniciais do século XX foram marcadas pelo surgimento de uma nova física, de uma nova cosmogonia e do "tempo geológico". De um modo bastante sintético, podemos situar historicamente alguns marcos do desenvolvimento científico dessas décadas para bem compreendê-las: descoberta da radioatividade (1896; Henri Becquerel), detecção do eléctron (1897; Joseph J. Thomsom), descoberta do elemento químico Rádio (1898; Marie e Pierre Curie), Teoria dos Quanta (1900; Max Planck), hipótese dos raios cósmicos (1902; Wilson), teoria do efeito fotoelétrico (1905; Albert Einstein), teoria especial da relatividade (1905; Einstein), teoria dos quadrivetores (1908; Minkowski), medida do valor da carga do eléctron (1909; Robert Millikan), corroboração da hipótese dos raios X (1911; Wilhelm Roëntgen), teoria planetária do átomo (1911; Ernest Rutherford), detalhamento da estrutura do átomo (1913; Niels Bohr), teoria geral da relatividade (1916; Einstein), desintegração do átomo (1919; Rutherford), teoria cromossômica da hereditariedade (1919; Hunt Morgan), hipótese do dualismo onda-partícula (1924; Louis de Broglie), conceito de "onda de probabilidade" para explicar o dualismo onda-partícula (1924; Bohr, Kramers e Slater), mecânica quântica (1925; Werner Heisenberg), mecânica ondulatória (1926; Erwin Schrödinger) e Princípio da Incerteza (1927; Heisenberg).

Estes exemplos servem para mostrar o surgimento das físicas nuclear e relativista, e sua importância no contexto científico do início do século. Também, a partir de 1926, quando Max Born especulou sobre a natureza probabilística dos eventos quânticos, o próprio conceito de realidade física subjacente foi estremecido. Logo em seguida, Heisenberg desferiu golpe mortal no determinismo clássico, mostrando que o objeto da experiência e o observador fazem parte de uma unidade indivisível. Ato contínuo, Niels Bohr, o revolucionário, afirmava que o "mundo quântico" não existe, mas apenas uma descrição abstrata feita em termos quânticos. O cientista perde então sua função de descobrir os segredos da natureza e passa a "criar" (construir) a natureza (Lavina 2004, 2006). A partir de 1930 a discussão polariza-se em dois grupos antagônicos principais, um liderado por Einstein, tentando provar a existência de uma realidade quântica independente do observador, e outro formado por Bohr, Heisenberg e Von Neumann, para os quais nada autoriza a se falar em realidade física independente do observador (Braga 1991).

Embora subordinada a este contexto principal, a Geologia estava bastante ativa, e em alguns aspectos, era tão polêmica quanto a Física. Em retrospectiva histórica, pode-se caracterizar a segunda metade do século XIX como a da procura de uma explicação plausível para a origem das cadeias de montanhas dobradas (e.g. Andes, Himalaia). Para tanto, foi necessária a criação e/ou desenvolvimento de uma série de conceitos acessórios, tais como os que sugeriam a existência de movimentos verticais na crosta (isostasia, subsidência e epirogênese), origem de falhamentos e dobramentos e origem do vulcanismo, além de especulações sobre a natureza plástica do magma do manto.

Ao final do século XIX, conhecia-se razoavelmente bem a evolução das grandes regiões montanhosas, desde a fase de subsidência inicial, em ambiente mari- 
nho, até a posterior inversão do relevo, com formação de montanhas dobradas. A pergunta crucial - por quê se formam montanhas? - permanecia sem respostas, porém o conhecimento sobre a evolução da crosta terrestre avançara de modo notável naqueles cinquenta anos.

$\mathrm{Na}$ última década do século XIX, o centro das atenções nas discussões geológicas começou a deslocar-se progressivamente para o problema da idade da Terra. A partir de Darwin e Lyell, começou a formarse um consenso de que a idade da Terra era maior que a indicada na Bíblia, sendo que neste final de século muitos geólogos falavam abertamente em centenas de milhões de anos (Carneiro et al. 2005). Estas especulações chocavam a opinião pública e científica, não obtendo grande aceitação. Para tentar colocar o problema de forma mais científica, Lord Kelvin (William Thomson), então considerado um dos maiores físicos vivos, em 1897 refez cálculos anteriores e propôs uma nova idade para a Terra. Com base na hipótese nebular da origem da Terra, elaborada por Laplace cem anos antes e considerada como verdadeira pela comunidade científica, Kelvin supôs que, partindo-se de uma massa em fusão a $4.500^{\circ} \mathrm{C}$, seriam necessários entre 24 e 40 milhões de anos para o planeta atingir a temperatura atual (Wyllie 1979, Cullen 2006). A autoridade de Kelvin e seu conhecimento poderiam (ou deveriam) fazer com que sua conclusão prevalecesse. Sua estimativa, porém, não convenceu Thomas Chamberlin (geólogo) e Forest Moulton (astrônomo) que, juntos, combateram Kelvin e a hipótese nebular de Laplace, o que veio a resultar, em 1904, na hipótese planetesimal, apresentada de forma completa em 1916 (Moore 1956). Arthur Holmes também se opos a conclusão de Kelvin e propos, com base em taxas de decaimento radiométrico, que a idade da Terra seria de 1,6 bilhão de anos (Holmes 1913).

Um ponto obscuro no panorama científico da época, não ocupando qualquer lugar de destaque nas discussões, dizia respeito à existência de alguns gêneros de animais e plantas, atuais e fósseis, em continentes geograficamente bastante separados. Esse era o caso da curiosa distribuição do molusco Helix pomatia (caracol de jardim) e de vermes lumbricídeos na borda oeste do continente europeu e leste da América do Norte, ou seja, na margem atlântica dos dois continentes. Em sedimentos do Permiano do Brasil e da África do Sul ocorriam abundantes restos esqueletais de pequenos répteis aquáticos (mesossaurídeos). Também era apontada a existência de restos de plantas semelhantes em rochas carboníferas da Índia, Madagascar, África do Sul e Austrália (relacionadas à "Flora Glossopteris"). A explicação aceita à época para solucionar estes e outros problemas sugeria a existência, no passado, de pontes intercontinentais contínuas e estreitas ligando o Brasil à África, Índia à Madagascar, Índia à Austrália e América do Norte à Europa (Fig. 2). Quando começou a pensar sobre a possibilidade de ajuste geométrico entre os continentes que limitam o oceano Atlântico, Alfred Wegener percebeu, de imediato, as extraordinárias implicações da distribuição geográfica destes organismos.

\section{A DERIVA DOS CONTINENTES Desde Francis} Bacon (1620) e Antônio Snider-Pellegrini (1858), espíritos "aventureiros" sempre fizeram referências à notável semelhança entre o desenho das linhas das costas leste da América do Sul e oeste da África. Neste sentido, Bacon, em um de seus últimos escritos, questionava que tipo de cataclisma teria ocorrido para separar estes dois continentes. No final do século XIX - início do século XX, Marcel Bertrand, Edward Suess e Frederick B. Taylor propuseram, independentemente, uma paleogeografia diferente da atual para o Neopaleozóico e Mesozóico. Suess, a partir da distribuição da Flora Glossopteris, sugeriu que a Índia, Madagascar, África e Austrália formavam então um único continente, que designou Gondwana. América do Sul e Antártica, onde a Flora Glossopteris não havia ainda sido descoberta, não faziam parte de Gondwana.

As ideias de Taylor, Suess e Bertrand não obtiveram penetração nos meios científicos, não conseguindo sequer promover debates sobre sua validade ou não. O mesmo não ocorreu quando a proposta foi feita por Alfred Wegener. Em 1910, raciocinando sobre a semelhança entre as linhas de costa da América do Sul e África, Wegener questionou-se pela primeira vez sobre a existência de movimentos horizontais na crosta terrestre. No ano seguinte, quase simultaneamente, tomou conhecimento da existência de répteis mesossaurídeos e Flora Glossopteris em continentes do hemisfério sul (mais Índia) e das ideias de Suess. Estudando a morfologia dos continentes que limitam o oceano Atlântico, encontrou semelhanças também entre as linhas de costa da América do Norte e do noroeste da África e entre Groenlândia e Europa. A partir destes "dados", postulou a existência, no Carbonífero, de um supercontinente (Pangea) que, ao final do Mesozóico ter-se-ia fragmentado em vários continentes menores: os continentes atuais. Esta hipótese foi apresentada numa conferência da Associação Geológica da Alemanha, em Frankfurt, no ano de 1912 e, mais tarde, transformada em um livro polêmico (Die Entstehung der Kontinente und Ozeane - 1915). A teoria despertou alguma curiosidade e foi discutida em toda a Europa, até o ano de 1923, quando foi considerada totalmente refutada. Na América do Norte, os debates estenderam-se até 1927, ano em que a American Association of Petroleum Geologists promoveu um grande encontro. Ao término dos debates, todos os argumentos de Wegener haviam sido refutados e a teoria declarada não científica. A partir desta data, os debates foram-se reduzindo até 1930 (ano da morte de Wegener), quando cessaram completamente, salvo por um geólogo (Alexander du Toit) para o qual provar a Teoria da Deriva dos Continentes passou a ser a "razão de vida".

Cabe agora salientar os pontos considerados positivos por Wegener para justificar a sua teoria e, após, os negativos, encontrados nas críticas contra ele dirigidas.

As evidências a favor da movimentação dos continentes Wegener dispunha, como evidências, o ajuste geométrico dos continentes que limitam o Atlântico, 


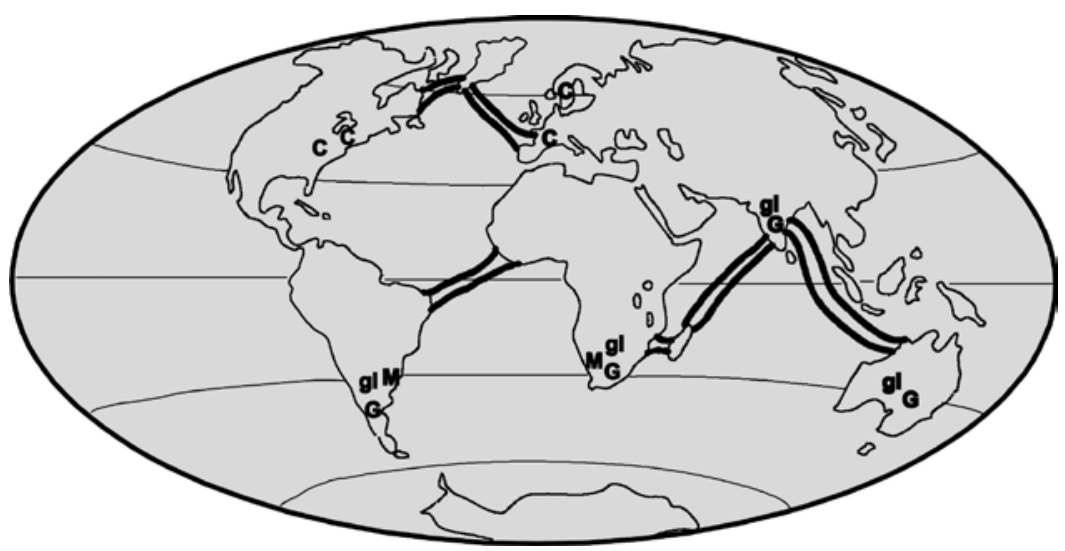

Figura 2 - Localização atual dos fósseis e indicadores paleoclimáticos do Permocarbonifero. As pontes de terra eram necessárias para justificar a existência de fósseis semelhantes em continentes distantes. Répteis mesossaurídeos (M), "Flora Glossopteris" (gl) e depósitos glaciais (G) e de carvão (C).

a distribuição da Flora Glossopteris e a ocorrência de répteis mesossaurídeos nos dois lados do Atlântico. Nas reedições de seu livro (1920, 1922 e 1929), foi acrescentando evidências favoráveis à sua teoria, principalmente de natureza climática (Lavina \& Fauth 2010). Observando a distribuição dos "sedimentos climaticamente sensíveis", tais como depósitos glaciais e camadas de carvão, ele acreditava ser possível reconstituir as posições antigas do equador e dos pólos. Em especial, isto poderia ser feito para o Carbonífero e Permiano. As extensas florestas que originaram os carvões da América do Norte e Europa indicariam a região equatorial, enquanto os depósitos glaciais encontrados nos continentes do sul e Índia evidenciariam as proximidades do polo sul. Os indicadores paleoclimáticos, quando ajustados sobre mapas atuais, tornavam-se francamente incoerentes. Havia necessidade de posicionar depósitos glaciais em latitudes muito próximas ao equador e florestas equatoriais em latitudes relativamente altas (Fig. 2). Ao contrário, assumindo-se um modelo no qual os continentes se encontravam unidos, automaticamente os depósitos glaciais do sul da América do Sul, África do Sul, Madagascar, Índia e Austrália formavam um todo uniforme, indicando a região polar; em sintonia perfeita, as florestas do hemisfério norte assumiam latitude equatorial (Fig. 3). Como decorrência complementar, o ajuste geométrico dos continentes eliminava o problema da "migração polar", então utilizada para justificar a existência de depósitos glaciais em latitudes hoje incompatíveis.

Wegener percebia também conflitos entre a distribuição dos cinturões montanhosos e as teorias existentes. No início do século, os movimentos verticais da crosta terrestre eram aceitos sem reservas, o mesmo não ocorrendo com os movimentos horizontais, simplesmente considerados inexistentes. Os movimentos verticais seriam de natureza isostática e os continentes, por serem menos densos, "flutuariam" acima das rochas que constituem o assoalho oceânico. Também, como referido no início, nesta época aceita- va-se que a Terra teria se formado a partir de uma massa em fusão, que resfriou durante alguns milhões de anos até atingir o estágio atual. Fica implícita nesta origem a existência de uma contração, significando que, com o passar do tempo geológico, seu diâmetro torna-se menor, acompanhando o resfriamento. Wegener via alguns problemas com esta teoria. Observando-se em um mapa a distribuição das grandes cadeias de montanhas, percebe-se facilmente que estas formam sempre cinturões estreitos e alongados. Ora, se a Terra estivesse contraindo continuamente em decorrência do resfriamento, as montanhas teriam, forçosamente, uma distribuição mais uniforme ao longo da superfície do planeta. O modelo contracional torna ainda mais notável a coincidência dos contornos leste da América do Sul e oeste da África.

A teoria das "pontes de terra" ligando vários continentes entre si apresentava uma série de contradições internas que não eram consideradas significativas pela comunidade científica do início do século (e.g. Termier \& Termier 1960). Segundo Wegener, sua existência violaria o princípio da isostasia pois teriam de ser constituídas por materiais menos densos que os do assoalho oceânico e, portanto, não poderiam ter desaparecido dentro destes como postulavam os seus defensores.

Ao longo dos anos, Wegener foi desenvolvendo a ideia de que vários fenômenos de natureza aparentemente muito diversa deveriam ser interrelacionados: “... podemos assumir uma coisa como certo. As forças que deslocam os continentes são as mesmas que produzem as grandes cadeias de montanhas dobradas. Deriva continental, falhas e compressões, terremotos, vulcanismo, ciclos transgressivos e migração polar são indubitavelmente conectados causalmente em grande escala" (Wegener 1929; p. 179).

A análise da argumentação de Wegener revela importante questão com relação ao "dado" científico. Ele utilizava essencialmente informações disponíveis nos periódicos especializados. Seus "dados" eram os resultados de pesquisas estratigráficas, sedimentológicas, pale- 
ontológicas e geofísicas, integralmente tomados como informação pontual, porém reorganizados e reinterpretados em suas implicações. A análise da bibliografia da edição de 1929 mostra que na base de dados da teoria da Deriva dos Continentes não existe qualquer informação publicada fora dos veículos reconhecidos pelas comunidades científicas envolvidas. Porém, toda informação obtida passava por uma precisa análise de suas condições de validade, e após, reinterpretada segundo a premissa da movimentação continental.

O mecanismo proposto para a Deriva dos Continentes A tentativa de propor um mecanismo para a movimentação das massas continentais levou Wegener a descartar mais alguns paradigmas do início do século. Para fundamentar o raciocínio, ele teve que considerar o substrato abaixo dos continentes como um fluido viscoso. Também assumiu que, se movimentos verticais são possíveis através deste fluido, os horizontais do mesmo modo o são. Precisava agora de uma força impulsionadora suficientemente poderosa para arrastar/empurrar os continentes. Que as forças envolvidas eram poderosas não havia dúvida, pois tinham o poder de comprimir massas rochosas e formar cadeias de montanhas tal como ocorreu quando do choque da Índia com a Ásia, gerando os Himalaias. Para justificar a migração da Índia para o norte, Wegener propôs o que se convencionou chamar de "fuga dos polos", ou seja, a força centrífuga existente na superfície do planeta, em decorrência do movimento de rotação, produziria uma resultante que deslocaria para o equador os continentes situados em latitudes intermediárias e altas. Já os movimentos com direção leste-oeste (América do Sul - África) foram considerados como consequência da atuação das marés sobre a crosta terrestre.

ARGUMENTOS CONTRÁRIOS À DERIVA DOS CONTINENTES "ao examinar idéias tão novas como as de Wegener não é fácil esquecer os prejuizos. ....seu livro não busca a verdade. Está defendendo uma causa e está cego para todos os fatos e argumentos que se falem contra ela" (geofísico Philip Lake, em 1923; in Hallam 1983).

Críticas a Wegener provieram de todos os lados, quase sempre dosadas com forte conteúdo emocional. Dizia-se, com frequência, que a hipótese não era científica, pois não se apoiava nas teorias existentes; ao contrário, ia contra a quase totalidade das teorias. Percebe-se hoje que não havia, nas críticas, argumentação técnica demonstrando a impossibilidade da movimentação continental. Os detratores de Wegener encontraram uma solução bastante simples para desacreditá-lo. Passaram a exigir da teoria, sempre, uma precisão incompatível com os conhecimentos da época. $\mathrm{O}$ ajuste dos continentes, feitos a partir da linha de praia, eram considerados deficientes (sabe-se hoje que a crosta continental prossegue mar adentro, em média até uma profundidade de $2.000 \mathrm{~m}$, sendo a curva traçada nesta profundidade a melhor para ajustar os continentes; Bullard et al. 1965). Com o tempo,

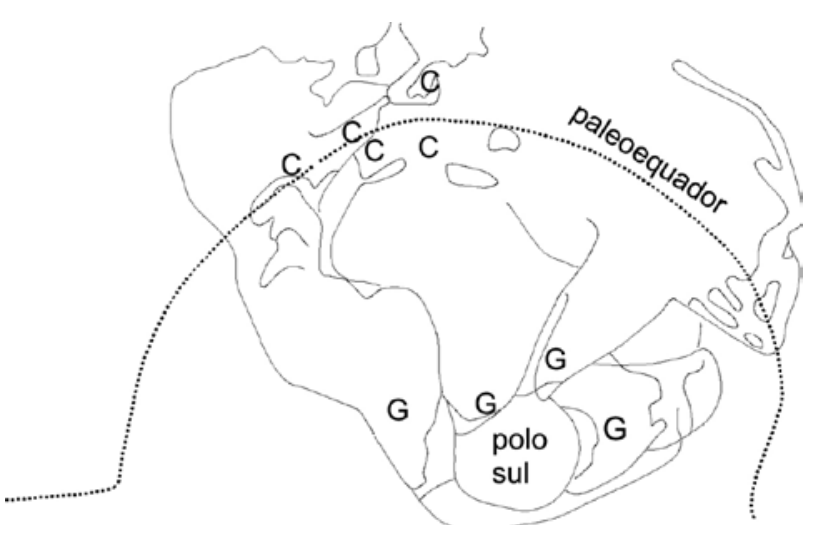

Figura 3 - Distribuição dos fósseis e indicadores paleoclimáticos do Carbonífero sobre o mapa do Pangea. Nesta situação, os depósitos glaciais $(G)$ delimitam a região do polo sul enquanto os carvões (C) marcam a faixa equatorial (modificado de Wegener 1927).

Wegener e du Toit foram conseguindo ajustes cada vez mais aprimorados, chegando a uma precisão de $90 \%$ - contudo, argumentava-se que não era de $100 \%$. Sua interpretação de que as grandes cadeias de montanhas dobradas, como os Himalaias e os Alpes, resultaram do choque entre continentes tinha dois sérios problemas. Em primeiro lugar, existiam grandes cadeias de montanhas em regiões onde não seria possível tal explicação (e.g. Andes). Para estas regiões, Wegener sugeriu que as montanhas foram formadas devido a resistência das rochas do manto ao movimento da crosta. Aqui, os oponentes detectaram uma contradição, pois, em outros locais do livro, as rochas do manto foram consideradas como um fluido viscoso (Hallam 1983).

Também, muitas hipóteses desenvolvidas nas décadas de 1940 e 1950, tais como a proposição da expansão do diâmetro da Terra (Egyed 1956) ou da alternância entre expansão e contração (Terra pulsante; Bucher 1933; Umbgrove 1947) que atingiam resultados diferentes, eram usadas como teste falseador da Deriva dos Continentes. Além disso, tudo o que era desconhecido à época, tal como a morfologia do assoalho das bacias oceânicas, era utilizado como prova em contrário, embora, talvez, pelo simples fato de ser desconhecido não devesse entrar na argumentação.

O falseamento do mecanismo proposto por Wegener $O$ antagonismo às ideias de Wegener não iniciou imediatamente após a sua divulgação, sendo encontradas, inclusive, algumas referências a geofísicos que "simpatizavam" com sua hipótese. Porém, a partir de 1928 a situação começou a mudar. Harold Jeffreys atacou, de forma demolidora, os mecanismos propostos por Wegener para a migração continental. Por intermédio de cálculos simples, demonstrou que as forças geradas pela rotação da Terra não teriam a menor possibilidade de ocasionar a "fuga dos polos". Também demonstrou que se as forças de atrito das marés fossem suficientemente fortes para separar dois continentes 
como América do Sul e África, seriam igualmente fortes para terminar com a rotação da Terra em um ano (Tarbuck \& Lutgens 2002).

As objeções levantadas por Jeffreys aos mecanismos da deriva dos continentes eram procedentes - os mecanismos causadores não poderiam ser os sugeridos por Wegener - e a teoria foi abandonada pela comunidade científica. $\mathrm{O}$ antagonismo exacerbado às ideias de Wegener começou após esta data e manteve-se praticamente inalterado até quase o final dos anos 1960. Cabe ressaltar, porém, que mesmo errando o mecanismo, Wegener acertou em cheio ao considerar as rochas do manto como um fluido viscoso, premissa que é hoje essencial ao modelo da Tectônica de Placas.

POLICIAMENTO IDEOLÓGICO “... Deste modo, a teoria da Deriva dos Continentes é um conto de fadas. ... Uma fantasia fascinante que tem capturado a imaginação de muitos" (geólogo Bailey Willis, in Hallam 1983).

Como a hipótese da Deriva dos Continentes era "irracionalmente atraente aos estudantes", sua divulgação passou a ser eficientemente bloqueada. Por questão de credibilidade, uma ciência formalmente constituida não poderia (como até hoje não pode) ser maculada por idealizações fantasiosas ou místicas. Algumas interessantes particularidades podem ser observadas na literatura escrita nas décadas de 1940 e 1950 . Havia um sistema eficiente de policiamento contra a divulgação da teoria. São raros os livros de Geologia ou de divulgação científica que citam Wegener ou suas ideias. Segundo Wyllie (1979), um candidato a cargo de professor em universidades americanas que falasse em "deriva dos continentes" não teria qualquer possibilidade de contratação. Hallam (1975) cita que a própria carreira do incauto estaria sob risco. No ambiente universitário, a teoria deveria ser banida por ser "... muito perigosa" (Harold Jeffreys) e produzir "... efeitos danosos sobre os estudantes" (Bailey Willis, ao receber a medalha Penrose da Geological Society of America, em 1944).

Nesta época, os mecanismos de policiamento eram tão eficientes que mesmo pesquisadores da teoria geossinclinal reconhecidos como "mobilistas", para quem os movimentos compressivos que deformavam os sedimentos e formavam as montanhas eram essencialmente horizontais, não discutem a Teoria da Deriva dos Continentes (e.g. Van Bemmelen 1955; Auboin 1965).

Existe um toque surrealista em muitos trabalhos desta época, claramente evidenciado nos estudos sobre paleomagnetismo. A partir da medição da orientação dos minerais magnéticos encontrados em rochas vulcânicas, é possível estimar, com boa precisão, a posição dos polos magnéticos no momento da formação da rocha. Os trabalhos sobre paleomagnetismo feitos na década de 1950 exibiam, quase sempre, coisas muito curiosas, como polos magnéticos localizados muito longe dos polos geográficos, por vezes até no equador. Também, a partir da análise de rochas vulcânicas de diferentes idades, percebia-se que os polos haviam andado "à deriva" pelo planeta. As linhas assim construídas eram designadas de "curvas de migração polar". Mais estranho ainda, os polos magnéticos de um continente muitas vezes não coincidiam com os polos dos demais, havendo, portanto, para cada período geológico, um polo norte e sul para cada continente - distantes milhares de quilômetros uns dos outros. Vários pesquisadores, observando estas curvas, viam ali uma prova concreta da deriva dos continentes, mas até meados da década de 1960 não podiam expressá-lo claramente para não ser estigmatizados, especialmente nos Estados Unidos. Hoje, os trabalhos de paleomagnetismo servem de referência para o posicionamento geográfico das diferentes placas litosféricas nas reconstituições paleogeográficas, mas, à época, eram utilizados apenas para mostrar a migração dos polos (Auboin et al. 1968, p. 493).

Exemplos interessantes da eficácia do policiamento ideológico pode ser encontrado nos trabalhos de Arthur Holmes e H. H. Hess. Holmes (1931) propôs que as correntes de convecção do manto (sugeridas por Griggs e Joly) tivessem força suficiente para transportar os continentes. Mas para reduzir as pressões por parte da comunidade científica, ao final do seu livro (Holmes 1944) retirou todo o potencial teórico da hipótese, deixando claro que esta era puramente especulativa, criada para atender necessidades e frisando que carecia de valor científico maior! Hess apresentou um trabalho em 1960, intitulado História das Bacias Oceânicas (publicado em 1962), sugerindo a hipótese da expansão do fundo oceânico e a decorrente movimentação dos continentes, em função das correntes de convecção do manto, mas, teve o cuidado de considerá-la apenas como uma "geopoesia" (Wyllie 1979).

Cada pesquisador inclinado a aceitar ou mesmo discutir abertamente qualquer mecanismo que implicasse na movimentação dos continentes teria que encontrar um viés para expressá-lo, pois admitir abertamente simpatia pela ideia induzia críticas: " $E$ fonte de profundo assombro que tal hipótese ... atraia algumas autoridades em suas fileiras de seguidores. São homens evidentemente hipnotizados pela ousadia das ideias de Wegener e por seu estilo literário brilhante" (Beloussov 1962).

1960 a 1963. Os anos do terror! Com o número de evidências favoráveis à mobilidade continental avolumando-se dia a dia, chegou um momento, especialmente no início da década de 1960 , no qual a situação tornou-se caótica. Os paradigmas antigos estavam ruindo, porém a comunidade não reconhecia algo novo para pôr no lugar. A partir de 1960, muitos geofísicos dedicavam sua atenção às anomalias magnéticas registradas nas rochas oceânicas. Estes estudos, novos e essencialmente teóricos, eram vistos com desconfiança, pois partiam de pressupostos básicos duvidosos, tais como a expansão do assoalho oceânico e inversões na polaridade do campo magnético terreste (Menard 1971).

As revistas especializadas de maior renome, em função do corpo consultivo ortodoxo, rejeitaram, nestes anos, alguns trabalhos que tornar-se-iam, caso aceitos, clássicos da Geologia. Como consequência, 
pesquisadores que hoje teriam seu nome associado ao maior paradigma da história da Geologia encontram-se praticamente no esquecimento. Como exemplo marcante, Wyllie (1979) destaca que a Nature e o Journal of Geophysical Research rejeitaram o trabalho de Lawrence W. Morley, onde era proposto que os fundos oceânicos guardariam a história das inversões do campo magnético terrestre e registrariam, portanto, as taxas de espalhamento do assoalho oceânico e a consequente movimentação continental. Analisando o trabalho, um dos consultores manifestou-se da seguinte forma: " $U m$ bocado de especulação que se torna conversa interessante em reuniões sociais, mas não é o tipo de coisa que deva ser publicado sob a égide cientifica". Posteriormente, F. J. Vine e D. H. Matthews conceberam modelo idêntico, que foi aceito pela mesma Nature (o consultor deve ter sido outro) ficando reconhecidos para a posteridade como figuras das mais ilustres da geologia do século XX. J. Tuzo Wilson, que mais tarde, juntamente com Vine e Matthews, viria a ser considerado um dos mentores da Tectônica de Placas, teve também um artigo rejeitado pelo J. Geophys. Res.

Mesmo na segunda metade da década de 1960, quando a expansão do assoalho oceânico ganhava adeptos, as coisas continuavam muito complicadas. Henry W. Menard relata em seu livro que muitos pesquisadores de Geologia marinha diziam a si próprios: “... as minhas observações não são compatíveis com a expansão dos fundos oceânicos e hei de demonstrar isto no momento oportuno, deitando abaixo esta idéia maluca; então, poderemos todos voltar ao trabalho" (Menard 1971).

A década de 1970 e a desconstrução de Alfred Wegener Quando a tectônica de placas passou a ocupar amplos espaços nos periódicos científicos, houve, em paralelo, a progressiva minimização da obra de Wegener. A análise da literatura deste período revela que, aos propositores do novo paradigma, não era interessante o consenso de que "finalmente encontrou-se o motor da deriva continental". Houve a necessidade de demonstrar a enorme importância da nova tectônica global na resolução de muitos e variados problemas, mesmo quando eles já haviam sido solucionados por Wegener. Afinal, para quem trabalha com correlações bioestratigráficas, paleobiogeografia ou mesmo paleoclimas, a aceitação da movimentação continental é decisiva, já a natureza do mecanismo não. Exemplos da desconstrução progressiva de Wegener ao longo das décadas de 1960 e 1970 são inúmeros. No livro intitulado "Implicações da deriva continental para as ciências da Terra" (Tarling \& Runcorn 1973), Wegener é omitido mesmo nos capítulos dedicados às evidências paleogeográficas, paleontológicas e paleoclimáticas da migração continental. No artigo onde é feito o ajuste paleogeográfico das biotas de répteis permo-triássicos (Colbert 1973), pesquisa cujos créditos iniciais cabem todos a Wegener, este não é mencionado, e o mapa do Pangea utilizado é de Dietz \& Holden (1970). Ainda neste livro, talvez a melhor síntese da subtração da importância de Alfred Wegener se encontre no início do artigo de J. R. Heirtzler sobre a evolução do Atlântico Norte: "Embora Wegener tenha produzido em 1914 o ajuste das praias do Atlântico Norte e estimado a separação [entre Groenlândia e Europa] como terciária, a história deste oceano não pode ser creditada antes do surgimento da teoria do espalhamento do assoalho oceânico (Heirtzler 1973; p.191).

\section{POR QUE AS IDEIAS DE WEGENER NÃO FO-} RAM ACEITAS? "[o método de Wegener] ...não é científico ... [consiste em] uma busca seletiva através da literatura para corroborar suas provas, ignorando os dados opostos a essa idéia, e finalizando em um estado de auto-intoxicação no qual a idéia subjetiva acaba sendo considerada como um fato objetivo" (paleontólogo E. W. Berry; in Hallam 1983).

Em uma tentativa de reconstruir a história da Deriva dos Continentes, parece incompreensível que os argumentos de Wegener não houvessem sido aceitos pela comunidade científica da primeira metade do século XX. Neste julgamento pesa, é claro, o notável avanço da ciência geológica dos últimos trinta anos, contexto no qual a nova tectônica global reina soberana. Analisando-se o grande volume de críticas dirigidas contra Wegener, percebe-se que não havia, nelas, argumentos contrários que hoje pareçam significativos. Os argumentos de Jeffreys, demonstrando a impossibilidade física de marés e fuga dos polos causarem a "Deriva", eram contrários apenas aos mecanismos propostos por Wegener, os quais não passavam de especulação. Os dados provindos da observação: morfologia de costas semelhante, fósseis semelhantes em continentes hoje bastante separados, distribuição linear das cadeias de montanhas e distribuição dos depósitos glaciais e carvões do Permocarbonífero não foram falseados por Jeffreys.

Mas, se hoje, com toda a moderna tecnologia em seu auxílio, a Tectônica Global mostra uma reconstituição paleogeográfica para Carbonífero e Permiano que difere, especialmente da elaborada por du Toit (1937), apenas por detalhes ínfimos (Lawver \& Scotese 1987), por que houve tanta relutância e foram necessários mais de cinquenta anos para a sua total aceitação?

Temos aqui que jogar com hipóteses. Como primeira tentativa referida em alguns trabalhos de meados da década de 1960, poderíamos assumir que a comunidade científica do início do século era refratária às novas ideias. Neste caso, como justificar o notável desenvolvimento da Física, Astronomia, Geologia e vários outros campos do conhecimento? Por acaso, a Teoria da Relatividade era menos temerária ou menos afastada do "senso comum da ciência", quando foi formulada em 1905? Afirmar, como o fez Einstein, que a massa não é uma constante universal, mas sim uma grandeza vetorial, variável em função da velocidade, que o escoamento do tempo varia com o inverso da velocidade da luz, que a luz pode ser desviada por campos gravitacionais, e portanto, não se move em linha reta no Universo, não é tão ou mais temerário que postular a movimentação de massas continentais? No entanto, a teoria da relatividade, apesar da fantástica 
mudança no conceito de realidade que ocasionou, pela substituição dos paradigmas newtonianos, levou menos de cinco anos para ser assimilada pelos físicos e leigos bem informados. Deste modo, considerações como as de Takeuchi et al. (1967) e Hallam (1975), de que a hipótese de Wegener era extremamente avançada (precoce) para a época, revelam talvez apenas algum tipo de preconceito contra os pesquisadores mais antigos.

Allègre (1983) sugeriu a existência de fatores de natureza mais psicológica que técnica, que teriam influenciado a não-aceitação da teoria: Wegener não era professor de Geologia e dedicava relativamente pouca atenção a Geologia, pois preocupava-se mais com meteorologia e exploração da Groenlândia; além disso, defendia sua teoria de forma sempre tranquila, jamais brigando ou reagindo de modo áspero. Deste modo, para a comunidade científica, apareceria mais como um “... amador astucioso, porém pouco digno de crédito". A argumentação de Allègre é significativa, porém a história mostra que as opiniões científicas de "amadores", mesmo quando amplificadas pela mídia, atingem pequena ou nenhuma penetração no meio científico.

Nesta linha de argumentação, trabalhos modernos insistem na existência de um preconceito contra Wegener pelo fato de não ser geólogo. A nosso ver, esta análise é superficial. Wegener não foi aceito por suas ideias, o fato de não ser geólogo foi apenas um fator adicional. Nessa época, muitos pesquisadores da história da Terra não eram geólogos, a começar pelo maior opositor da movimentação dos continentes, o matemático Harold Jeffreys. Admitindo-se a existência do preconceito, a causa mais provável seria o fato de Wegener utilizar em seu apoio informações publicadas por cientistas que eram contrários à deriva dos continentes. Este fator "psicológico" deve ter sido importante, pois muitos críticos de Wegener reprovavam a sua busca "seletiva" de dados na literatura. Além disso, seu currículo não poderia ser confundido com o de um incompetente. Wegener era considerado um meteorologista brilhante, e era um pioneiro em vários aspectos, entre eles o de utilizar a reflexão de ondas sísmicas para estimar a espessura do lençol de gelo da Groenlândia (Lee 2009). Aqui se delineia um caminho interessante a ser explorado: por que, ao contrário do que ocorreu no caso de Suess ou Taylor, a teoria chamou tanto a atenção da comunidade científica? Talvez a resposta passe também pelo fato de que seu proponente era um pesquisador renomado. Em 1911, Wegener foi descrito pelo climatologista russo Alexander Woeikoff como “... a nova estrela ascendente da Meteorologia".

A compreensão dos motivos da rejeição às ideias de Wegener tem que considerar, necessariamente, na rede de saber empírico do início do século $\mathrm{XX}$, as condições de possibilidade de discussão de uma nova hipótese. Em um espaço de quatro anos Wegener publicou dois livros. O primeiro, sobre a termodinâmica da atmosfera, abordava questões pertinentes para os meteorologistas, como, por exemplo, as trocas de energia térmica que possibilitam a formação da gota de chuva no interior das nuvens. Neste livro, toda a construção estava contida no horizonte teórico da Meteorologia e as ideias de Wegener foram discutidas e aceitas.

Problemas? Onde? Em primeiro lugar (e talvez a causa principal), deve ser ressaltado que a posição antiga dos continentes não era considerada um problema no início do século XX. Em outras palavras, Wegener encontrou solução para problemas que só constituíamse em problemas em sua cabeça e somente nas de mais três outros cientistas (Taylor, Suess e Bertrand). Havia algumas dificuldades, por certo, quanto à curiosa distribuição do réptil Mesosaurus e da Flora Glossopteris. Mas, os mesossaurídeos, sabia-se, apresentavam claras evidências de adaptações aquáticas e estavam contidos em rochas tidas como marinhas. Seria realmente um problema sério a sua presença no Brasil e África do Sul? Muitos geólogos admitiam que estes animais pudessem ter, ao menos uma vez, atravessado o Atlântico. De qualquer modo, era mais fácil imaginar um réptil aquático e marinho atravessar o oceano do que supor um continente deslocar-se $5.000 \mathrm{~km}$. Mesmo para os paleontólogos que não aceitavam esta ideia, a ligação Brasil/ África por uma ponte de terra estreita e contínua, parecia muito mais simples que a explicação de Wegener. Quanto à Flora Glossopteris, a justificativa também era simples - plantas semelhantes ocorrem em quase todos os lugares, e de qualquer modo, a presença de pontes intercontinentais também resolvia este problema.

As evidências acumuladas por Wegener, du Toit, e talvez a contragosto, também por centenas de pesquisadores contrários à "Deriva", sobre a evolução paleoclimática dos continentes do hemisfério sul, eram simplesmente descartadas.

Por outro lado, sua teoria era também contrária à hipótese nebular de Laplace, considerada então como verdadeira (Beloussov 1962). Se a Terra esta contraindo, os continentes tendem a se aproximar, não se afastar. Este aspecto da teoria de Wegener era considerado pelos críticos como muito importante. Ela ia contra as teorias existentes; ou como foi concluído por Thomas Chamberlain no congresso da Americam Association of Petroleum Geologists (AAPG) de 1928: "se acreditarmos na hipótese de Wegener, temos de esquecer o que aprendemos nos últimos setenta anos e começar tudo novamente". Wyllie (1979) relata o "sarcasmo mortal" com que eram apresentadas, no congresso da $A A P G$, as evidências contra a teoria.

Tentando tornar mais claros os porquês da não aceitação da Teoria da Deriva, podemos principiar por discutir a conclusão a que chegaram quase todos os principais oponentes de Wegener: a hipótese não era científica!

Novidade! “... todo o conhecimento cientifico se apoia em observações anteriores. O cientista nunca trabalha isoladamente, ao contrário, apoia suas observações nas dos que o precederam" (Bertin 1965, ao final de sua crítica sobre a Deriva dos Continentes).

Parece-nos claro que Wegener não poderia ter chegado à "Deriva" utilizando os procedimentos metodológicos tradicionais de sua época. Se aceitarmos como válidos os paradigmas do início do século, entre eles o 
que afirmava que a Terra encontra-se em fase de contração, não é admissível, em nenhum momento, postular a movimentação das massas continentais. A Teoria da Deriva é, pois, totalmente nova, não evolui de qualquer teoria anterior. Este ponto é fundamental. Não existe, no início do século XX, qualquer teoria da ciência formal que possa ser vista como ponto de partida ou antevisão da Teoria da Deriva dos Continentes. Cabe ressaltar que a hipótese de Suess sobre a possível união dos continentes que continham a "Flora Glossopteris" não obteve qualquer penetração nos meios científicos ou não científicos. A hipótese foi trazida ao debate por Wegener.

Neste aspecto, a Deriva dos Continentes tem o mesmo status da teoria heliocêntrica e da teoria da relatividade. Wegener, assim com Copérnico e Einstein, percebeu que a solução do seu problema não poderia ser apoiada nas teorias existentes. Houve um rompimento com a tradição científica de seu tempo. Rompimento que acarretava inclusive dificuldades de comunicação, pois havia a necessidade de introduzir novas variáveis e descartar as antigas.

$\mathrm{O}$ caráter de novidade trazida pela Teoria da Deriva dos Continentes, se amolda para algo que poderíamos designar de objeção empírica, ou seja, utilizando as palavras de Takeuchi et al. (1967).”... o geólogo deve trabalhar com persistência por longos periodos na coleta de dados e, só então, coordenando-os, tentar interpretar os problemas de geologia que, em geral, envolvem grande quantidade de material e informações complexas". Segundo Takeuchi et alii, teorias hoje consagradas iniciaram os seus primeiros passos no fim do século XVIII.

Observação versus paradigma Vários filósofos modernos, entre eles Popper (1968, 1972), Kuhn (1976, 1989) e Feyerabend $(1985,1991)$ têm demonstrado que as descobertas surpreendentes, inesperadas, inconcebíveis até então, surgem apenas quando quebramos uma tradição metodológica "irrepreensível", ou vamos contra paradigmas tidos como verdadeiros e inquestionáveis pela comunidade científica.

Sem entrar no mérito da delimitação ciência/ não ciência, podemos tentar reconstituir o caminho de Wegener, ou se regredirmos mais no tempo, o de Bacon, Snider-Pellegrini e Suess. Todos, em algum momento (assim como muitas outras pessoas), notaram semelhanças morfológicas entre as linhas de costa da América do Sul e África. Aquilo que para a maioria era apenas uma curiosa ou notável coincidência revelouse, para uns poucos, um importante conflito entre a observação e as teorias ou crenças existentes. Para estas pessoas o conflito exigia uma solução, e esta, fosse qual fosse, teria de ser uma nova teoria, não compatível com as existentes até então. Bacon sugeriu apenas algum tipo desconhecido de cataclisma, Snider-Pellegrini postulou a "Grande Inundação", com características sobrenaturais. Já Suess não ficou impressionado com a semelhança das linhas de costa, mas apenas com a existência da Flora Glossopteris em vários continentes. Deste modo, curiosamente, o seu Gondwana não in- cluía a América do Sul e a Antártica, onde a flora não havia sido descoberta. Quando tomou conhecimento da existência de répteis mesossaurídeos no Brasil e África do Sul e do trabalho de Suess, em 1911, Wegener simplesmente assumiu que o Gondwana de fato existiu, que incluía também a América do Sul e a Antártica, e imediatamente após começou a tentar sua delimitação de modo mais preciso. Sem qualquer envolvimento com as teorias aceitas em sua época, seu passo seguinte foi verificar a possibilidade de outros "ajustes geométricos" entre os continentes. Poucos meses depois Wegener anunciava ao mundo que, no Neocarbonífero, todos os continentes estiveram unidos em uma única massa de terra que, posteriormente, veio a se fragmentar. Apenas o rompimento definitivo com grande parte da tradição científica de sua época permitiu-lhe chegar a esta conclusão.

Torna-se importante frisar que, se em qualquer momento, Wegener tivesse considerado determinadas interpretações da Geologia formal como pertinentes, não teria proposto a Deriva dos Continentes. Deste modo, adjetivos a ele atribuídos, como os de amador ou louco, não eram irracionais ou mal intencionados; eram, ao contrário, profundamente sinceros, fruto de toda uma análise criteriosa, embasada nos resultados da ciência formalmente constituída.

\section{"Copernicus" Wegener "As suposições "óbvias" da imobilidade dos continentes e das pontes de terra ... estão erradas. Os continentes se movem" (Wegener 1929, p.17).}

Tentando buscar mais elementos para nossa análise, podemos aqui discutir também algumas semelhanças e diferenças entre a contextualização da teoria de Wegener com a de Copérnico. Do ponto de vista estritamente científico, a questão transcendental da imobilidade x mobilidade da Terra, no contexto social do século XVI, é análoga a da imobilidade $\mathrm{x}$ mobilidade dos continentes no contexto social século XX.

Ao tempo de Copérnico, a astronomia ptolomaica, com seus círculos dentro de círculos, se encontrava em situação crítica (Kuhn 1989). Não que houvesse conflitos insolúveis entre observação e paradigma, mas a complexidade gerava dúvidas. Copérnico, portanto, viveu em um período, não de questionamento objetivo, mas pelo menos de perplexidade com o modelo geocêntrico de Ptolomeu. Mas Copérnico tinha imensas dificuldades, pois não podia buscar na observação evidências em favor de suas ideias. Havia, em sua época, poucos indícios capazes de provar/justificar a rotação da Terra e o seu movimento em torno do sol (Feyerabend 1985).

A teoria de Copérnico surge fora de sintonia com as tradições e crenças de sua época, sem apoio em idealizações anteriores. Em verdade, Aristarco, quase dois mil anos antes, já havia formulado um sistema solar semelhante, mas que não obteve aceitação. Cabe destacar, na comparação que estamos efetuando, que o Aristarco da Geologia seria Suess. Apenas que no caso de Aristarco os problemas para os quais seu modelo heliocêntrico seria uma explicação só tornaram-se 
angustiantes após dois mil anos. No caso de Suess, cinquenta anos bastaram para revelar integralmente as anomalias.

Podemos discutir também um aspecto mais subjetivo: a motivação que levou à formulação da teoria. Por que Copérnico defendia um modelo heliocêntrico? Evidentemente, conforme relatado por Copérnico (1566), a extrema complexidade do modelo ptolomaico, em que eram necessários mais de 50 círculos para explicar os movimentos dos planetas, constituía-se em forte argumento contra a sua possibilidade. Porém, apesar da complexidade, o sistema ptolomaico permitia previsões bastante satisfatórias das posições dos planetas. Não havia, propriamente, um conflito, e além disso o modelo heliocêntrico não permitia predições mais precisas que o geocêntrico (Burtt 1983, p. 29).

Koyré (1982) apresentou a hipótese de um comportamento místico da parte de Copérnico. Segundo o autor, assim como Kepler, também Copérnico, embora de forma velada, era uma espécie de "adorador do Sol". Considerava o Sol como a emanação visível de Deus, pois o Sol garante a vida; sem ele o planeta seria escuro e gelado. Deste modo, sendo a representação visual de Deus, por que a Terra, e não o Sol/Deus, deveria ocupar o centro do Universo? Alguns comentários de Copérnico, entre eles a referência a Hermes Trimegisto que denominava o Sol como o "Deus Visível”, também na descrição de seu novo modelo, onde o Sol se encontra sentado em seu "trono real", guiando sua "família de planetas" e ressaltando a beleza de colocar a luz do Sol no centro para iluminar o todo por igual (Burtt 1983, p. 44-46), parecem, em princípio, apoiar a inferência da "Divindade do Sol".

Se esta foi a verdadeira motivação de Copérnico, como sugere Koyré, temos aqui uma extraordinária corroboração da afirmação de Popper (1968) de que não importa como surge uma hipótese, importa apenas como ela explica algum fenômeno da natureza. $\mathrm{Ou}$, conforme afirma Feyerabend (1985), não é importante nem mesmo que a teoria contrarie, além das teorias aceitas na época, também os próprios dados da observação (e.g. o Sol girando em torno da Terra), ou seja, contrarie a própria noção do que seja realidade.

Faltou um Galileu para completar a obra de Wegener Outra chance de Wegener teria sido, como no caso de Copérnico, a providencial existência de um defensor eficiente de suas ideias. Em verdade, o proto-Galileu existiu: o geólogo Sul-Africano Alexander L. du Toit, cientista notável e grande divulgador do trabalho de Wegener. Porém, este pesquisador cometeu, do ponto de vista estritamente técnico, um grande equívoco: passou a vida inteira coletando e colecionando evidências favoráveis à movimentação continental, mas descuidou de procurar os mecanismos para justificá-la. Du Toit ocupou-se durante muito tempo em refinar o encaixe das peças que formaram o Gondwana. Cabe a ele, mais do que a Wegener, a idealização usual do Pangea fragmentando-se primeiro em dois grandes continentes, um a norte (Laurásia) e outro a sul (Gondwana), então separados pelo Mar de Tethys. Também, du Toit dedicou atenção às rochas formadas em depressões relativamente estreitas e alongadas, chamadas geossinclinais. Estas depressões têm como característica, em uma fase de inversão de sentido de deslocamento, tornarem-se regiões montanhosas. Situações deste tipo eram encontradas na Austrália e Tasmânia, Antártica (Montanhas Transantárticas), África do Sul (região ao sul do Cabo) e América do Sul (Sierra de La Ventana, ao sul de Buenos Aires). Em 1937, apresentou uma proposta na qual todos estes geossinclinais, hoje separados por milhares de quilômetros de oceanos, faziam parte de um único, que designou de Geossinclinal de Samfrau (du Toit 1937) (Fig. 4).

Hoje, as mais modernas reconstruções de Gondwana e da continuidade física de seus "geossinclinais", feitas a partir dos novos dados geofísicos, de imagens de satélite, paleomagnetismo, computação gráfica e toda a tecnologia disponível, corroboram integralmente a proposição de du Toit, tal como expresso por Lawver \& Scotese (1987).

Apesar do trabalho notável de du Toit, à comunidade científica interessava somente a discussão do mecanismo capaz de mover continentes. Sem ele, ou sem, pelo menos, um proto-mecanismo razoável, todas as evidências relacionadas seriam, como o foram, sistematicamente descartadas.

Um mecanismo plausível para a deriva dos continentes encontrava-se já sugerido na última edição do livro de Wegener (1929), mas a sua importância não foi percebida por du Toit. No capítulo referente aos argumentos geológicos em favor da deriva, Wegener discute os resultados de Émile Argand sobre a compressão associada à formação dos Himalaias: “... estamos aqui envolvidos com um gigantesco empurrão no qual o bloco siálico indiano [lemuriano no original] foi forçado por baixo do bloco asiático" (Wegener 1929; p. 85 da edição inglesa).

Ao final do livro, Wegener diz que G. Kirsch (em trabalho publicado no mesmo ano) tem feito uso do conceito de correntes de convecção do manto (Sima no original)."Junto com a idéia de Joly que o Sima abaixo dos blocos continentais está aquecido devido ao elevado conteúdo de rádio, e que em regiões oceânicas ele esfria, Kirsch assume a circulação do Sima através da crosta. Ele sobe até o limite inferior dos continentes, de onde flui para as regiões oceânicas, onde desce, retornando aos continentes após alcançar grandes profundidades. Devido à fricção resultante, ele [Kirsch] diz, o Sima tende a quebrar o invólucro continental e forçar a separação dos fragmentos. ...Esta idéia aparentemente oferece uma explicação razoável para a abertura do Atlântico" (Wegener 1929; p. 178 da edição inglesa).

Temos aqui uma descrição ainda pouco técnica, porém quase precisa da separação América do Sul/África.

Em outro local do livro Wegener também afirma: "Quando, por exemplo, Molengraaff diz que a dorsal meso-atlântica mostra que a Africa teria derivado deste ponto para o leste, eu não posso discernir em sua afirmação qualquer discordância com a Teoria da Deriva. ... relativo à dorsal, a América derivou para 


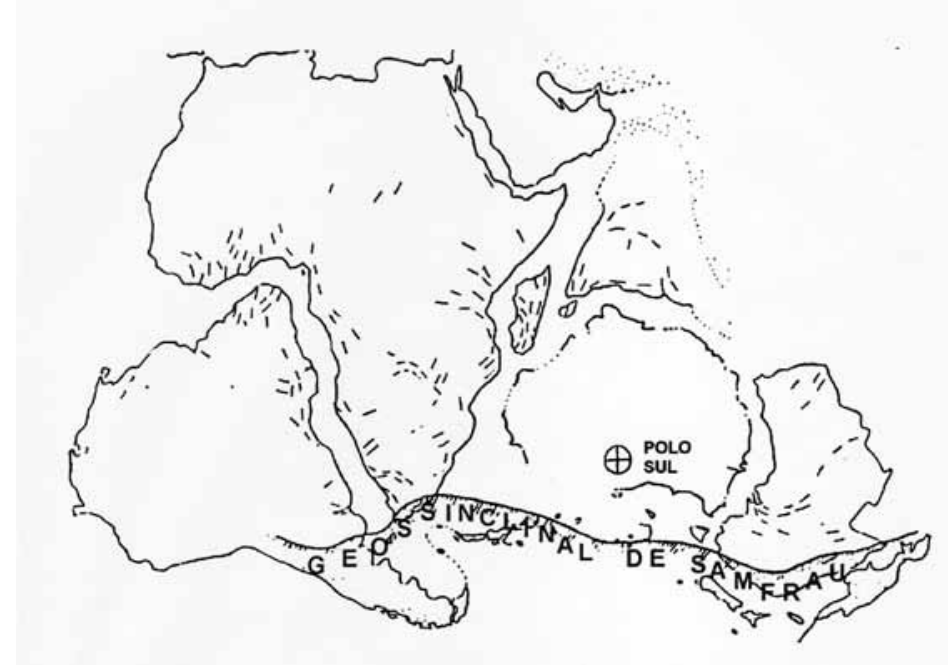

Figura 4 - O continente de Gondwana e a distribuição espacial do geossinclinal de Sanfrau (du Toit 1937).

oeste e a África para leste, aproximadamente a mesma taxa" (Wegener 1929; p. 148 da edição inglesa). Outros elementos precursores da tectônica de placas podem ser extraídos da última edição do livro, como a idéia de que os rift valleys do leste africano representem o estágio inicial (incompleto) de separação entre dois blocos crustais (p. 189-191).

Faltou pouco, muito pouco. Talvez, apenas mais alguns anos de vida - não houvesse morrido prematuramente - e a Tectônica Global (pelo menos um embrião) surgiria ainda na década de 1940 . Situado fora dos caminhos da ciência oficial, Wegener não tinha qualquer chance de ser aceito; ou melhor, teria uma se, como Albert Einstein, houvesse conseguido propor um mecanismo convincente para a movimentação continental.

WEGENER E A ESCOLA DE MARBURG A originalidade de Wegener deve refletir, forçosamente, uma visão de mundo muito especial. Ele teve a coragem de descartar a quase totalidade dos paradigmas da Geologia, paradigmas construídos ao longo de dezenas de anos e à custa de imensos esforços por parte de toda uma comunidade. Substituiu-os, sempre que necessário, por hipóteses altamente improváveis (segundo a óptica dos paradigmas descartados). Hipóteses criadas para explicar, por vezes, um único dado "anômalo".

Sem dúvida alguma, o modo de proceder de Wegener revela traços de personalidade, mas também pode refletir algo mais, conforme tentaremos abordar.

Alguns pesquisadores da história da filosofia dos séculos XIX e XX costumam relacionar o período que vai de 1871 a 1933 com a "Escola de Marburg", que inicia quando Herman Cohen propõe a "volta a Kant", buscando investigar a ligação entre ciência e filosofia transcendental. Posteriormente, Paul Natorp e Ernst Cassirer dedicar-se-iam à "teoria do conhecimento", em parte apoiada em reinterpretações de Platão, Descartes, Leibnitz e Kant. Nesta visão, filosofia só tem sentido se vinculada à ciência. $\mathrm{O}$ método sobressai-se ao conteúdo científico. O método domina a visão filosófica da Escola de Marburg; para Cohen, é o método que permite a constituição dos objetos (Philonenko 1974). Destaca-se, nos pesquisadores desta escola, o questionamento profundo a respeito da origem do conhecimento, o método como base para constituir o conhecimento, a abordagem matemática da lógica do conhecimento e sua utilização como método de estudo de filosofia.

AEscola de Marburg floresceu por curto período. Essencialmente positivista, atrelou a filosofia à ciência newtoniana, e acusou, em consequência, os duros golpes da "Relatividade" e da Mecânica Quântica. A partir de 1920, instituiu-se uma crise na Escola, quando Natorp e Cassirer enveredaram por caminhos inconciliáveis. Em especial, deflagrou-se uma crise científica, pois a concepção filosófica da Escola estava edificada sobre uma visão científica superada. A morte de Cohen, a desistência de Natorp e a fuga de Cassirer da Alemanha quando da ascensão de Hitler ao poder (1933), encerraram este ciclo do pensamento filosófico (Philonenko 1974).

Se tudo ocorreu assim, tendo a Escola de Marburg fracassado em sua tentativa de agregar a filosofia à ciência, qual sua importância em uma abordagem sobre Alfred Wegener?

Em primeiro lugar a coincidência de local e época-Wegener era professor da Universidade de Marburg na mesma época em que Cohen, Natorp e Cassirer desenvolviam suas ideias - e com o seu método de trabalho, que privilegiava sempre os dados. Wegener, ao contrário da maioria dos pesquisadores de sua época (ou mesmo dos que vieram depois), nunca forçava o encaixe dos dados nas teorias mais aceitas pelos seus colegas (ou então os descartava por não se adequarem às teorias). Pode-se aqui aventar uma vinculação direta entre o processo de geração de teoria de Wegener e o método desenvolvido por Cohen, segundo a qual o trabalho do historiador depende, em essência, da rigorosa separação das hipóteses formais como condição para a fundamentação de uma teoria (Patton 2004).

Cabe ainda referir que a visão da Geologia 
como ciência essencialmente histórica, perfeitamente delineada nos trabalhos de Wegener, antecipava o pensamento de Cassirer. Quando discute o trabalho do historiador, que lida com fatos históricos, pertencentes, portanto, à um tempo que passou para sempre, Cassirer (1944; p.294) mostra que a descrição das modificações do planeta ao longo do tempo geológico também revela eventos únicos, que nunca podem repetir-se do mesmo modo ou ocorrer na mesma ordem uma segunda vez. Neste sentido, compara o trabalho do geólogo ao do historiador. Como vimos, esta é a condição básica que resulta da evolução paleogeográfica e paleoclimática da Terra segundo Wegener. Pode ter havido, evidentemente, um processo de realimentação, com as ideias de Wegener influenciando o pensamento de Cassirer.

Embora não existam referências explícitas, o posicionamento filosófico de Wegener com relação à ciência: o questionamento total, audacioso e altamente criativo, sem barreiras, a fixação nos dados e método e não nas teorias existentes, mostram que este tinha o "espírito de Marburg" perfeitamente internalizado.

Wegener partiu de uma suposição e a utilizou para fazer avançar o entendimento sobre o passado da Terra. Formulou, em verdade, uma hipótese transcendental, pois reorganizou a evolução paleogeográfica desde um ponto que se estendia para além de qualquer possibilidade de experimentação. Sua pesquisa se desdobrava para um universo simbólico que transcendia o mundo dos objetos físicos. Somente através da mediação desse simbolismo seria possível captar os dados e utilizá-los de modo objetivo (organizar os eventos paleogeográficos e paleoclimáticos).

CONSIDERAÇÕES FINAIS A história da teoria da Deriva dos Continentes é clara demonstração de que a evolução dos conhecimentos ocorre de forma bem menos estruturada do que o usualmente considerado. Os cientistas, antes de tudo, são seres humanos. Têm aspirações, crenças, medos, orgulhos, teimosias...

A possibilidade de continentes imensos movimentando-se sobre um manto fluido era tão afastada do senso comum que, de certo modo, dificultava o raciocínio. Para geólogos e geofísicos, apenas após a formulação de um mecanismo plausível, ela poderia ser discutida. Como no caso de Copérnico e Einstein, primeiro a própria realidade (ou o que era considerado como real à época) teria de ser modificada. Kuhn e Feyerabend demonstraram, a partir de muitos exemplos, que toda idealização teórica que contrarie $o$ aceito por quase todos como realidade tem pequena possibilidade de sucesso.

Deste modo, a hipótese da Deriva dos Continentes experienciou tendência natural do conhecimento científico. Visualizada como processo histórico, a ciência tem imensas dificuldades em administrar os grandes desvios de rota - as grandes revoluções. É normal, portanto, que uma teoria que proponha algo inusitado seja, no primeiro momento, rejeitada. Entretanto, demonstrando algum sucesso na resolução dos quebra-cabeças propostos pela ciência, ela passa a atrair a atenção para si. Com o decorrer do tempo, o êxito continuado faz com que um número cada vez maior de cientistas comece a raciocinar em acordo com a nova teoria (Kuhn 1976).

Esta deveria ter sido a tendência natural. Mas, com a Deriva dos Continentes, tudo se passou de modo diferente. Com o decorrer dos anos, quase todos os geólogos e geofísicos mundialmente renomados comprometeram o peso de sua autoridade para negá-la. Apesar disso e a contragosto dos próprios cientistas, as evidências favoráveis iam-se acumulando em proporção quase geométrica. Como em um processo de realimentação contínua, o calor dos debates fazia com que, cada vez mais, o peso da autoridade tivesse de ser usado para não permitir a aceitação da ideia. O poder da autoridade passou então a ser utilizado para ameaçar inclusive a carreira de quem tentasse levar a ideia adiante. $\mathrm{Na}$ década de 1950, a única sustentação do policiamento ideológico era a ausência de um mecanismo convincente para movimentar os continentes.

Nos anos 1950, os ideais da ciência geológica confundiam-se com os ideais dos geólogos e geofísicos mais proeminentes. $\mathrm{O}$ rancor com relação às ideias de Wegener continuou a existir, mesmo quando um mecanismo convincente começou a ser proposto, a partir de 1962. Isto deveu-se justamente ao fato de haver sido "destruída" grande parte da obra de cientistas muito renomados. Mais grave ainda, quase todos tiveram que publicar, às pressas, artigos demonstrando a Tectônica de Placas, e em consequência, a Deriva dos Continentes. Isto se fez absolutamente necessário para escapar do adjetivo de reacionário.

No início dos anos 1970, poucos eminentes pesquisadores não haviam ainda aderido ao novo paradigma, e em especial Vladmir V. Beloussov e A. A. Meyerhoff, chamaram a si a tarefa de desafiar a nova ortodoxia que se estabelecia, coletando dados e observações que não se enquadravam na Tectônica de Placas. Porém, no momento da plena aceitação de um novo paradigma, com todos os importantes quebra-cabeças que se propunha solucionar, suas ideias não podiam mais ser bem recebidas pela comunidade científica. E eles tornaram-se, subitamente, reacionários, apagando parte do prestígio conquistado ao longo de toda uma vida dedicada à pesquisa.

Agradecimentos Aos profs. Ático Chassot e José Oliveira e aos revisores da RGB pela pertinência das críticas e sugestões. Em especial ao revisor prof. Celso dal Ré Carneiro por todo o auxílio prestado.

\section{Referências}

Allègre C. 1983. L'Écume de la Terre. Librairie Artheme Fayard, Paris, $387 \mathrm{p}$.
Auboin J. 1965. Geosynclines. N.York, Elsevier Publ., 335 p. Auboin J., Brousse R., Lehman J-P. 1968. Precis de Géolo- 
gie. Tome 3 - Tectonique, Morphologie, le globe terrestre. Paris, Dunot, 606 p. (Dunot Université 562).

Beloussov V.V. 1962. Basic Problems in Geotectonics. New York, McGraw-Hill, $816 \mathrm{p}$.

Bertin L. 1965. La Terre notre planète. Paris, Librairie Larousse, $568 \mathrm{p}$.

Braga R. 1991. A percepção originária de kant na Física do século $X X$. Brasília, Editora da UnB, 163 p.

Bucher W.H. 1933. Deformation of the Earth's Crust. An Inductive Approach to the Problems of Diastrophism. Princeton University Press, 530 p.

Bullard E.C., Everett J.E., Smith A.G. 1965. The fit of the continents around the atlantic: a symposium on continental drift. Phil. Trans. R. Soc. London, Ser. A, 258:41-51.

Burtt E.A. 1983. As bases metafísicas da ciência moderna. Brasília, Editora UnB, 266 p.

Carneiro C.D.R., Mizusaki A.M.P., Almeida F.F.M. 2005. A determinação da idade das rochas. Terree Didatica, 1(1):6-35.

Cassirer E. 1944. Antropologia filosófica. Ensaio sobre o homem. São Paulo, Ed. Mestre Jou, 374 p. (tradução 1977).

Colbert E.H. 1973. Continental drift and the distribuition of fóssil reptiles. In: Tarling D.H. \& Runcorn S.K. (eds.) Implications of continental drift to the Earth sciences. London, Academic Press, 1:393-412.

Copérnico N. 1566. As revoluções dos orbes celestes. Lisboa, Fundação Calouste Gulbenkian, 658 p. (reedição e tradução sem data).

Cullen K. 2006. Earth Science: The People Behind the Science. New York, Chelsea House Publishers, 166 p.

Dietz R.S \& Holden J.C. 1970. The break-up of Pangaea. Sci. Am., 223(4):30-41.

Du Toit A.L. 1937. Our wandering continents. Edimburgo, Oliver and Boyd, $366 \mathrm{p}$.

Egyed L. 1956. The change in the Earth's dimensions determined from palaeogeographical data. Geofisica Pura Applica, 33:42-48.

Feyerabend P. 1985. Contra o método. Rio de Janeiro, Francisco Alves, $487 \mathrm{p}$.

Feyerabend P. 1991. Adeus a razão. Lisboa, Edições 70,370 p

Hallam A. 1975. Alfred Wegener and the hypothesis of continental drift. Scientific American, 232(2):88-97.

Hallam A. 1983. Great geological controversies. Oxford, Oxford University Press, $183 \mathrm{p}$.

Heirtzler J.R. 1973. The evolution of the North Atlantic ocean. In: Tarling D.H. \& Runcorn S.K. (eds.) Implications of continental drift to the Earth sciences. London, Academic Press, 1:191-196.

Holmes A. 1913. The age of Earth. London, Harper \& Broters, $189 \mathrm{p}$.

Holmes A. 1931. Radioactivity and earth movements. Trans. Geol. Soc. Glasgow, 18:559-606.

Holmes A. 1944. Principles of physical geology. New York, Ronald Press, 532 p.

Koyré A. 1982. Estudos de história do pensamento cientifico. Brasília, Ed. UNB, 388 p.

Kuhn T.S. 1976. A estrutura das revoluções cientificas. São Paulo, Editora Perspectiva, Debates, 257 p.

Kuhn T.S. 1989. A tensão essencial. Lisboa, Edições 70, $422 \mathrm{p}$.
Lavina E.L. 2004. O século XX e as rupturas entre o real científico e o senso comum. Filosofia Unisinos, São Leopoldo, 5(8):123-37. Disponível em: http://www.unisinos.br/ publicacoes_cientificas/images/stories/Publicacoes/filosofia_v5n8/art07_lavina.pdf.

Lavina E.L. 2006. A geologia e o processo histórico (ou, sobre como se constrói um passado a marteladas). Gaea, Unisinos, 2(1): 29-39. Disponível em: http://www.unisinos.br/publicacoes_cientificas/gaea/art05_lavina.pdf.

Lavina E.L. \& Fauth G. 2010. Evolução geológica da América do Sul nos últimos 250 milhões de anos. In: Carvalho C. \& Almeida E. (eds.) Biogeografia da América do Sul: padrões e processos. Editora Roca (no prelo).

Lawver L.A. \& Scotese C.R. 1987. A revised reconstruction of Gondwanaland. In: McKenzie G.D. (ed.) Gondwana Six: structure, tectonics and geophysics. Geophysical Monography. Amer. Geophys. Union, Washington, 40:17-24.

Lee J.A. 2009. Wegener, Alfred. The Encyclopedia of Earth, National Council for Science and the Environment, EUA. Disponível em: http://www.eoearth.org/article/wegener, alfre. Acessado em 22 nov 2009.

McCoy R.M. 2006. Ending in ice. The revolutionary idea and tragic expedition of Alfred Wegener. Oxford University Press, $194 \mathrm{p}$.

Menard H.W. 1971. Science: grouth and change. Cambridge, Harvard University Press, MA, 215 p.

Moore R. 1956. The Earth We Live On: The Story of Geological Discovery. N. York, Alfred A. Knopf Publisher, 416 p.

Philonenko A. 1974. A Escola de Marburgo: H. Cohen, P. Natorp, E. Cassirer. In: Chatelet F. (ed.) História da Filosofia. Rio de Janeiro, Zahar Editores, p. 188-210.

Patton L. 2004. Hermann Cohen's history and philosophy of science. Doctoral Thesis, McGill Univ., Montreal, 202 p.

Popper K.R. 1968. A lógica da pesquisa científica. São Paulo, Cultrix, $567 \mathrm{p}$.

Popper K.R. 1972. Conjecturas e refutações. Brasília, Ed. UNB, $450 \mathrm{p}$.

Takeuchi H., Uyeda S., Kanamori H. (eds.) 1967. Debate about the earth. San Francisco, Freeman \& Cooper, 237p.

Tarbuck E.J. \& Lutgens F.K. 2002. Earth: an introduction to physical geology. New Jersey, Prentice-Hall Inc., 670 p.

Tarling D.H. \& Runcorn S.K. (eds.) 1973. Implications of continental drift to the Earth sciences. London, Academic Press, Vol. 1, 622 p.

Termier H. \& Termier G. 1960. Atlas de Paléogéographie. Paris, Masson Éditeurs, 99 p.

Umbgrove J.H.F. 1947. The pulse of the Earth. Nijhoff, The Hague, $358 \mathrm{p}$.

Van Bemmelen R.W. 1955. Tectogenèse par gravité. Annales Société Géologique Belge, 64:95-123.

Wegener A. 1929. The origin of the continents and oceans. London, Methuen \& Co LTD, 248 p. (tradução da quarta edição alemã (1929) por John Biram, com introdução histórica de B. C. King, sem indicação de data).

Wyllie P.J. 1979. A Terra. Nova Geologia global. Lisboa, Fundação Calouste Gulbenkian, 384 p.

Manuscrito ID 16069

Submetido em 23 de novembro de 2009 Aceito em 11 de junho de 2010 